\title{
Film and the Uncanny, Shakespeare Making Possible Things Not so Held, Communicating with Dreams ${ }^{1}$
}

\author{
Martin Orkin \\ University of Haifa and Sakhnin College
}

\begin{abstract}
This essay supports the view that present day cinema as an art form in its own right - rather than film always as adaptation of a literary text - provides an additional pedagogic and comparative opportunity for the analysis of aspects of Shakespeare's early modern texts. The essay takes as point of departure aspects of the uncanny as evoked in the cinematic experience. It then focuses upon aspects of experience and growth, as well as upon problems attached to language and narrativity as these are explored both in film-texts by Pedro Almodóvar and by Eytan Fox, and also in plays by William Shakespeare.
\end{abstract}

KEYWORDS: Cinema, pedagogic, comparative, experience and growth, language and narrativity, uncanny.

Studies of adaptation seek, amongst other goals, "to understand not individual texts, but rather the relationships that exist between texts." ${ }^{2}$ Comparative studies seek this too, but collocate usually very disparate texts, linked not by processes of adaptation but rather by

\footnotetext{
${ }^{1}$ I should like to express my warm gratitude to the various readers of Sederi Yearbook of the Spanish and Portuguese Society for English Renaissance Studies for extremely helpful criticisms, suggestions and advice in the writing of this essay.

2 Cutchins, Raw and Welsh (2010): "Introduction." Dennis Cutchins (2010:107) foregrounds the "persistent double-mindedness" which "the use of film in the classroom" engenders in students, although he speaks in the context specifically of the study of adaptations of literary works. Other more general studies of film and literature, but - differing from my present interest - of film as specific adaptations of literary works, include Davidson (1997); Carroll (2009); and Hopkins (2009).
}

$$
\text { (G) ederi } 21 \text { (2011): 49-70 }
$$

https://doi.org/10.34136/sederi.2011.3 
symmetry of concern. As part of just such a second, comparative, endeavor, I want to collocate certain instances of cinema, one of the great art forms of the twentieth and twenty-first century, with some of Shakespeare's texts. In choosing contemporary cinema I am proposing that we actively use appropriate aspects of our presentday location and its cultural knowledges and practices as one additional point of entry for the study of Shakespeare's early modern work. We are after all, arguably, to a significant extent always, perforce, local readers, inescapably located within our own experience, knowledges and languages. I support, then, the view that films from our own time and place provide one additional opportunity for the reading of Shakespeare's texts. ${ }^{3}$ I emphasize, though, that in exploring relationships between aspects of film and aspects of play, I never seek to imply by the terms "cinema" or "film" some kind of adaptation of Shakespeare's plays, or film as servant to the Bard, film as "subaltern" coefficient of a primary, Shakespeare master or mistress "text."4 In what follows I have in mind, rather, a more dialogic engagement between different cultural artifacts, understood, in their equation, as equal, independent terms.

I begin this essay with brief delineation of some aspects of the uncanny, which the experience of cinema entails. Such aspects suggest not only processes initiated by the cinema, and apparent too

\footnotetext{
${ }^{3}$ See, for example, Simkin (2006).

${ }^{4}$ There has been of course extensive interest in "Shakespeare and Film." Recent works, such as Cartelli and Rowe (2007) or Burnett and Wray (2006) continually broaden our understanding of processes of adaptation as well as increase our sense of the working of cinema. However, although interested in cinema, such or other work is always ultimately fixated on the Shakespeare text as origin and the particular film in question as adaptation. Keller (2004:1) for instance, seeks "sightings of Shakespeare" in popular culture, and "Shakespeare's artistic legacy" or "films that 're-cognise' Shakespeare, using him to support their social message." Starks and Lehman trace "the trajectory of Shakespearean cinema from its early role as agent of cultural mediation to its later incarnation as an agent of ideological agitation...disclosing the untold story of Shakespeare renaissance in the film industry while investigating the implications of our enduring fascination with the unspeakable preoccupations of this prolific playwright" (2002:20). Recently, even on a thread in the Shaksper List, regarding research into Shakespeare and Film, one correspondent writes of David Bevington's collection on the subject, "Yes, we did use [...] Bevington's text and as a teacher, I can say I found his book provided just the right context, one that included a balanced examination of text and film, with some energy devoted to live performance. In short, while students viewed comparative scenes from, say, four Macbeths, they never lose sight of the text and its primacy" (James 2010).
} 
in the theatre experience but evident also in Shakespeare's plays. To illustrate this further I focus upon selected intersections of the presentation of education, growth, and problems of narrativity in Pedro Almodóvar's Bad Education, and in William Shakespeare's The Winter's Tale. The political unease evident in these two works as this relates to growth and education becomes my focal point in examining, more briefly, related aspects of Eytan Fox's The Bubble and William Shakespeare's Hamlet. These two works, in their presentation of youth, and matters of language, knowledge and education, foreground, especially, the political uncanny.

\section{$\mathbf{I}$}

Certain aspects of Sigmund Freud's discussion of the uncanny lend themselves to consideration of the phenomenon of the uncanny precipitated by the cinematic experience. Freud (2003:134) famously argues that the uncanny denotes the apprehension of or the return of something strangely, disturbingly, familiar. He suggests, too, that a sense of the uncanny also involves in part "the idea of a 'double' (the Doppelgänger) [...] a person may identify himself [or herself] with another and so become unsure of his [or her] own true self, or [s] he may substitute the other's self for his [or her] own. The self may thus be duplicated, divided and interchanged" (Freud 2003:142). In her discussion of Freud's das Unheimlich (the uncanny, the "unhomely"), Susan Linville, (2004) helpfully uses the term "unhomey" for the uncanny, and, for Freud's das Heimlich (the familiar, the "homely") the term "homey." The process of doubling is, as Freud argues it, itself both "homey" and "unhomey," both a "defence against annihilation" and the "uncanny harbinger of death" (Freud 2003:142). For Freud, the uncanny brings with it, as well, a "feeling of helplessness that recalls the helplessness we feel in certain dream states" (144). It has the "feature of the unintentional return" (144).

In the cinema, as Nicholas Royle (2003:79) has it, "you are [always] in the dark and 'on your own,' in various ways, reminded of, and engaging in 'dream-work'" (77), confronted by celluloid images or by the "doubles" emanating from the "celluloid ghosts of ... actors' bodies" (78). Crucially, behind the silver screen there is nothing. The willingness of present-day audiences to return again and again to what the unknown darkness of the cinema may 
prevision, is in itself suggestive of, on the one hand, a homey habit of return to a dream-like condition but on the other hand a return whose outcome remains partly unknown and potentially also unhomey, uncanny, always there and not there.

The uncanny is in its effects nothing if not complex. Freud himself emphasizes the aspect of terror that the uncanny entails, involving "a frightening element [...] something that has been repressed and now returns. This species of the frightening [...] would then constitute the uncanny" (2003:147). But Freud recognizes at once that the terror is mixed, also "homey" and familiar. "[T]his uncanny element is actually nothing new or strange, but something that was long familiar in the psyche and was estranged from it only through being repressed" (148). The (only temporary) darkness of the cinema auditorium enables the audience, within the fixed time of screen presentation, more easily to engage with or "play" with what appears, too, strangely familiar. Susan Linville noting the "potentially frightening interchangeability, doubling and lack of clear boundaries" that words such as "canny" and "uncanny" or "heimlich" and "unheimlich" themselves denote, observes at the same time that "[a]lthough such uncertainty is potentially terrifying in life, as Freud indicates, in art and literature, aestheticization can render such ambivalence enjoyably terrifying" (2004:16). Such "enjoyably terrifying" play, moreover, can have a range of implication. It may for instance represent, as Mark Pizzato suggests, inner mental processes, ${ }^{5}$ display, as Susan Linville argues, deconstructive energy (Linville 2004:19-20), ${ }^{6}$ or again, provide, as Maurizio Calbi and others maintain, means of addressing the

\footnotetext{
${ }^{5}$ Pizzato suggests the extent to which characters both onscreen and onstage, "are phantom limb figures and spectral personalities projected from numerous neuronal mappings of Self and Other in the intersubjective, yet alienated, human brains of writer, directors, actors, technicians and spectators - through the creative sharing of specific plots and embodiments on the stage or screen" (2006:203).

${ }^{6}$ Linville in her critique of Freud's essay takes up this aspect, to propose for the "aesthetics of the uncanny", too, its "deconstructionist potential" as in Bhaba's argument which she cites, that "feminism makes "visible the forgetting of the 'unhomely' moment in civil society" (1994:10-11). It thereby reveals "the patriarchal, gendered nature of civil society and disturbs the symmetry of private and public which is now shadowed or uncannily doubled by the difference of genders which does not neatly map onto the private and public but becomes disturbingly supplementary to them."
} 
"other" in the self. ${ }^{7}$ Such instances of play help to account too, for those very elements of attractiveness (the "homey-ness") in the uncanny, despite its simultaneous "unhomey-ness."

The uncanny is then, as is the case with our revisits to the cinema, compellingly reiterative but in mixed ways. In the darkness of the cinema auditorium the audience undertakes repeatedly not only to entertain sometimes pleasurable identification with the screen's dream figures, but also to assume instabilities in identity and experience that partly informs imaginative engagement with "screen" characters, "screen" landscape, "screen" action. The element of the unknowable and the dangerous, attached to the uncanny that characterizes also the unpredictable turns of cinematic experience, may, lastly, also be juxtaposed against Freud's interesting but itself also uncanny reluctance to acknowledge the intellectual uncertainty that the uncanny brings with it. This too is something familiar but frightening. He asks, "where does the uncanny effect of silence, solitude and darkness come from? [...] these are conditions under which children are most often seen to express fear" (2003:253). Freud ponders here the strangely disturbing, the "not fully knowing what we think we know or experience," that childhood experiences, one amongst several marks of the uncanny. Significantly though, as if he himself enacts his own fears of it, from the start, but also intermittently throughout the essay, Freud repeatedly seeks to minimize the contention that the uncanny entails "intellectual uncertainty" (125). That this suggests an effort at repression or denial, however, at one point betrays itself directly. After discussing the fear of children, Freud admits: "And can we completely discount the element of intellectual uncertainty,

\footnotetext{
${ }^{7}$ Thus Calbi discussing the play of the uncanny and focusing on aspects of the relation between images of the "foreign" and the viewer, observes, "as both Freud and Lacan insist, although in slightly different terms, the 'estranging' and foreign image that keeps on returning from without, is nothing but one's own projected image" (2005:28). Linville notes how, from the 1980s, "theorists increasingly reworked Freud's theory to historicize uncanniness within the frameworks of the ethnic, racial and sexual dynamics of particular nations, cultures and histories and especially in relation to post-colonialism, migratory labour and globalization" and she notes Julia Kristeva's focus "on the foreignness of migrant workers within the modern metropolitan nation and on the correspondence between these strangers without and the uncanny strangers that exist within the psyches of native citizens" (2004:18).
} 
given that we have admitted its importance in relation to the link between the uncanny and death" (153).

In these, amongst many other ways, it may be argued, too, that the movies, albeit commercially, "do" the uncanny - simulate the frightening and the non-comprehendable or fully knowable, as well as simulate playful aspects of the "there" and "not there-ness" of human experience - more successfully nowadays than a twentiethfirst century performance theatre demonstrably on the decline. But the experience of cinema still helps to foreground for us what it is that, ultimately similarly, once enthralled or still, to a degree, enthralls stage audiences. As in the cinema, there is only on stage, for the moment of performance, a (ghostly) enacted "presence." In the theatre, we are, too, in the presence of stage sets and design (at least in present-day theatre performance) that are fabrications of a non-existent location, and in the "presence" of adults who "play" roles, who are uncannily "scripted," there on the stage, but not there, doubled, actors who "play" characters. In the theatre auditorium there are, too, adults, themselves en-scripted by their own discursive cultures and education but clearly willing to "play" - to engage in "dream-work" - with what may be both there in front of them on the stage, but not there, or with what may or may not be within themselves.

In such contexts, what used to be called "the willing suspension of disbelief" is now for us too easy a description for the complicated processes that may ensue from the agreement adults make when they watch a play that simulates, or re-shuffles, "life." Audiences in a theatre, like audiences in the cinema, allow an uncanny bringing into question, or "play", of who or what is "there" on stage. In this, they may be said, too, to entertain apprehension of the invasive or inflexible "there" and "not-thereness" of experience, or of learned (discursive) knowledges - sometimes, the presence or absence of their own learned knowledges, or the possibility of other knowledges. They face for duration of screening or performance, a bringing into question of who or what they themselves are, have been taught they are, or may be. 


\section{2}

If experience can only be identified by means of language, both visual and verbal, we have long since registered the "there" and the "not-thereness" that inevitably attaches to aspects of any narrative attempting to identify or report experience. The embodying or discursively constructionist nature of all language has also long since been noted. Such concerns are readily discoverable in aspects of the camera's gaze in the schoolboy visit-to-the-country sequence from Bad Education to which I now turn. ${ }^{8}$ They are evident, too, I will later argue, in the presentation of Leontes's gaze in the early acts of The Winter's Tale.

Bad Education is a film self-reflexively engaged with the uncanny nature of a schooled, rigorous (fascist and theological) "scripting" that nonetheless produces in the adults who emerge from it - in assumedly mature, that is, conventionally imagined, adult identities - a "not there-ness." ${ }^{9}$ It contemplates a "schooled" scripting that is, instead, in its impact and consequences, dislocatory and disjunctive. Almodóvar indicates in his film the institutionalized education of fascist Franco's Catholic Spain, for example, by means of shots indexing sadistic authority and regimentation, juxtaposed repeatedly against images of boyhood rendered vulnerable to its practices and its discursive insistences. These are processes of educative growth that produce a doubleness in experience. A doubleness notably underlined, at the end of the schoolboy visit-tothe-country sequence by the close-up of the face of the child Ignacio. Literally split by such educative practice and the violent experience it masks, Ignacio says, after his literature teacher has tried sexually to abuse him, "Un hilo de sangre dividía mi frente en dos, y tuve el presentimiento de que con mi vida ocurriría lo mismo. Siempre estaría dividida y yo no podría hacer nada para evitarlo" [A trickle of blood divided my forehead into two. I had the feeling the same thing would happen with my life. It would always be divided and I couldn't help it].

Amongst the multiple aspects of the working of the camera's gaze during this sequence, we may briefly list Almodóvar's use of

\footnotetext{
${ }^{8} \mathrm{I}$ use the translations provided in the Pathe edition of the DVD.

${ }^{9}$ The film is discussed in D'Lugo (2006); Strauss (2006); Acevedo-Muñoz (2007); Sotinel (2010).
} 
panning shots from right to left, which suggest, against the more lyrical effects of the semi pastoral images or the lyrical aspects of the music-over sound track, a mood of unease. Indeed the song itself mingles haunting melody with lyrics that again indicate Almodóvar's interest in the mixedness, doubleness, unknowability of human experience. ${ }^{10}$ Almodóvar uses multiple other cinematic devices to qualify or complicate his pastoral iconography. The closed frame shots of the bamboo undergrowth suggest a claustrophobic impenetrable containment of, at the same time, shots presenting ostensible youthful pastoral beauty. Again, the fixed unchanging proxemic range that separates the singing Ignacio and his teacher, the expressions we see on each, the one uneasy, the other timidly provocative, underline the boy's vulnerability and powerlessness. The long shot of him falling to the ground is yet a further filmic device that underlines the boy's complete aloneness.

If the gaze of cinema, and its consequent meanings, is in such or other ways partly the product of multiple camera and editing techniques, the early modern gaze may be said to be partly the product of the use of "technologies" of the tongue, that is, of rhetoric. It is true of course that while the cinematic audience is always dependent on the gaze of the camera, theatrical audiences

\footnotetext{
${ }^{10}$ The song alludes to Breakfast at Tiffany's, a film in which Audrey Hepburn sings a song about two drifters, the subject of the film. Bad Education is also about two drifters (Ignacio and Enrique). Almodóvar rewrote the lyrics of the song for his film: "Moon river... no te olvidaré, | yo no me dejaré llevar | por el agua, agua turbia | del río de la luna | que suena al pasar.| Río y luna, dime dónde están, | mi dios, el bien y el mal, | decid.| Yo quiero saber | qué se esconde en la oscuridad | y tú lo encontrarás, | río y luna... adiós.| Mi luna, ven y alúmbrame,| no sé ni dónde estoy, por qué.| Oigo el rumor de aguas turbias | que me llevan lejos, muy lejos de mí.| Moon river... dime dónde están | mi dios, el bien y el mal, | decid.| Yo quiero saber | qué se esconde en la oscuridad| y tú lo encontrarás, Moon river... adiós." A loose translation of this version follows: "Moon river... I will not forget you, |I will not get carried away|By the water, muddy water|Of the river of the moon/Which sounds like happening.| River and moon, tell me where they are, | My god, right and wrong, | Tell me.|I want to know $\mid$ What he hides in the dark|And will you find it,|River and moon... good-bye.|My moon, come and light me,|I know neither where I am nor why.|I hear the rumor of muddy waters $\mid$ - they take me far, very far from myself. |Moon river[...] tell me where they are $\mid$ My god, right and wrong, |Tell me. |I want to know|What he hides in the dark|And if will you find it,|Moon River... Goodbye" (taken from the internet: http://ask.metafilter.com/14841/ Moon-River-toSpanish-via-Almodóvar-and-back-into-English).
} 
may more readily observe several gazes on stage. Indeed, although I have space to focus only on aspects of Leontes's diseased gaze, The Winter's Tale balances Leontes's particular, diseased gaze against that of others, most notably Hermione's and Paulina's, suggesting, in the argument of Susan Snyder and Deborah T. Curren-Aquino in the final scene, "a new, more exclusive patriarchal structure (at least by early modern standards), one in which the female presence emerges as strong, vibrant, assertive, and perhaps, most important, desirable" (2007:57). ${ }^{11}$

In the case of Leontes's particular gaze, cinematic techniques involved in the camera's gaze, are analogous to the rhetorical devices upon which he notably depends to clothe, identify, or articulate into being (schooled) hauntings of misogynist anxiety about the body and its sexuality. Certain of Leontes's extended early speeches in Act I register directly the potential ambiguity that is one condition within which the human gaze must operate: the "entertainment" he sees "may" be one thing or "may" be (like the cinematic dependence on particular techniques of camera photography and editing) another (I.ii.107-117). Indeed, during the lines containing the famous crux on "affection" his language registers further how projects of the mind may be lost in the language used to articulate them, may make "possible things not so held," may communicate [like the cinema] "with dreams [...] With what's unreal [...] [be] coactive" to fellow "nothing" (I.ii.137-141).

To handle, simplify and resolve his discursively learned fear of what he sees in the friendship between his pregnant wife and his close friend, with its culturally invited early modern misogynist ambiguities, he draws also in the opening act of the play on a plethora of rhetorical devices. In "But to be paddling palms and pinching fingers, $\mid$ As now they are, and making practised smiles $\mid$ As in a looking-glass, and then to sigh, as 'twere|The mort o'th'deer" (I.ii.114-117) or in, "[y]et they say we are|Almost as like as eggs women say so, | That will say anything. But were they false $\mid$ As o'erdyed blacks, as wind, as waters, false | As dice are to be wished by one that fixes $\mid$ No bourn 'twixt his and mine, yet were it true [...]" (I.II.128-133), he turns from one simile to another to convince himself

\footnotetext{
${ }^{11}$ All quotations from The Winter's Tale are taken from Snyder and Currren-Aquino (2007).
} 
that his (culturally learned) fears are reliable. Some of these comparisons are, in turn, also significantly proverbial and a glance at Snyder and Curren-Aquino (2007) shows how reliant Leontes also becomes upon such learned culturally reassuring proverbial articulation about experience to "order" his inner uncertainties. Proverbs were a respected rhetorical device in the early modern period, and hundreds of them were memorized at school. But in the manner in which Polonius in Hamlet uses them, or, indeed, as dramatic characters elsewhere in Shakespeare's plays sometimes do, as easy and learned "authoritative" points of reference, proverbs can in such usages be an index of either, in Polonius's case a conventional and lazy gaze, or, elsewhere the mistaken, insecure or anxious attempt to gloss over or contain the complexity or sometimes alarming incomprehensibility of experience. Thus Leontes, again to clothe his gaze, sometimes draws on the learned proverbial imagery of cuckoldry, referring not simply, and rather indirectly to that which his "brows" like not (I.ii.118) but specifically to the category of "neat" animals, "the steer, the heifer, and the calf" (123), or to the "rough pash, and the shoots that I have" (I.ii.127). Other of his inflammatory images is similarly indicative of overheated reliance, in the articulation of his gaze, upon "technologies" of rhetoric. Such repetitions foreground not merely the "infected" nature of the gaze of Leontes, but the uncanny doubleness involved in the (learned) discursive languages of the tongue that, like the art of make-up, or gardening, or costuming - or, indeed, the cinema construct the gaze, em-body the tale.

Bad Education's presentation in the sequence we have looked at, of an admittedly melodramatic but nonetheless iconic incident of violence, itself foregrounds the uncanny "there" and "not thereness," even the divisiveness, of present and of past experience or "schoolings," that reside in memory, that cumulatively by way of visual or verbal language layer and process human comprehension. But Almodóvar and indeed Shakespeare both reflect and explore the intersection of narrativity and growth in human experience, in these works, even more directly.

In Bad Education, a succession of complicated visual shots reminders that our pasts can only be remembered hauntings, known and not known, narrated, moreover, in multiple ways - everywhere layer Almodóvar's presentation of Ignacio's story. We might recall 
that early in the film, Ignacio's entire tale in the form of a manuscript story entitled "The Visit" is offered to the film director Enrique. At the beginning of the visit-to-the-country sequence, we see Enrique reading Ignacio's account of this incident. As he reads, the audience sees the film Enrique envisions he might make of a tale which (although Ignacio's) is remade cinematically as Enriquo's version of it. As we have noted, Ignacio's voice-over leads at once to shots of him singing the song "Moon River," to the accompanying guitar of the teacher priest. These shots are juxtaposed against shots evoking the quasi-pastoral harmony of the picnic as the boys rhythmically dive into or swim in the river. In turn these shots are framed by or juxtaposed against shots not only of the manuscript itself, but of the director Enrique reading the "tale". By such as well as other visual and aural juxtapositions, Almodóvar insistently reminds the cinema audience that what happened between the boy and the teacher has become, now, and can only be, a matter of memory, a re-making that is a haunting, one (amongst multiple) possible ways of "telling" (revisiting) the past.

The "Ignacio" narrative voice-over, as Enriquo reads, and what follows, offers to the audience what will be only one of several visual accounts or enactments or narrations of the same "past," that will in due course unfold in Bad Education. Later in the film in a different retelling of the past, Almodóvar intersperses shots of the camera crew filming re-enacted scenes of the tale of "The Visit," or shots of the actors moving out of the "doubling" their roles have, in performance, just required, and into their own everyday lives. Such a filmed enactment of the filming of the tale itself, or of the human beings who have, as actors, recently performed cinematic roles, turning again to their own lives, underlines Enrique's directorial as well as the actors' performative interventions in this particular retelling of the tale. Even later in the film, the literature teacher, Father Manolo in his new identity as the married father and publisher Mr Berenguer will offer yet another account of "The Visit." The past, there and not there, itself, becomes, in the very retellings of it, en-scripted by successive and in each case different (learned) discursive locations of gaze, active intervention, bias.

Such cinematic self-reflexivity implies too, unreliability in narrativity, which is our only means of identifying experience or recalling the past. As we know, each time experience is reiterated it 
is also transmuted and re-constructed in the language chosen to articulate it. Experience is in this sense uncannily there and not there, always to be mediated, by those discursive "technologies" verbal and visual, selected in narration. In cinema these are (primarily of course) visual narratives. And as I remarked, by means of its narrative gaze Bad Education itself, situates, for audience in film auditorium, or private viewer and computer screen, the learned, discursive, but simultaneously uncanny "fixities" of a Fascist and Catholic Spain, within disjunction and dislocation.

The verbal tissue of The Winter's Tale is similarly infused with a sense of, in physical and mental being and development, a possible sweetness in human experience reiteratively narrated, but at the same time dangerously not known as well as known. The play is also, as in Bad Education, haunted by the interface of growth, development, experience itself, on the one hand and education, culture, politics, the "technologies" of narrativity, on the other. It is rich with allusion or reference to education and sexuality, the discursive molding of childhood into adulthood. ${ }^{12}$ Thus, as the play begins, we are told that Leontes and Polixenes were "trained together in their childhoods" (I.i.21) and we hear of the court's expectations for the growth and future its royal children. We witness the presence on stage of a queen, almost at the full term of her pregnancy, surrounded by her son, himself only a child, and his father. During Act 1, Polixenes and Leontes contemplate their own past childhoods. They articulate, at various moments, processes of growing and learning, the acquisition, for instance of doctrines of "ill-doing" (I.ii.69), when Polixenes famously envisages an edenic

\footnotetext{
${ }^{12}$ When, amongst the diverse aspects of childhood she explores, Carol Rutter, asks, "Can the adult remember childhood without contaminating it with adult knowingness?" (2007:98), she hints at the problem I am tracing in the present essay, which is the uncanny aspect attached to, in her words again," growing up. Becoming adult" (100). She argues that contemporary productions of The Winter's Tale, know "more about Shakespeare's play than criticism does...Theatre knows the play starts with the child" (110). If Rutter is extensively concerned with contemporary theatre performance's validation of the concern with aspects such as education in the play (see 96-153), I argue that the cinema provides an additional route to this concern, one engaged with the extent to which adult life is "rooted in the past...remember[ed] organically" (112-113). But in the present essay I am interested in this, specifically, as means of foregrounding the play's concern with the uncanny aspects and effects of institutional education. See also Chedgzoy, Greenhalgh, and Shaughnessy, (2007) and Sommerville (1992).
} 
pastoral boyhood, untainted by that "shameful" sexuality. This (in uncomplicated heterosexist and misogynist mode) he asseverates, albeit in polite jest, only girls and young women in time bring "to cross the eyes" (I.ii.78), of boys and young men. In turn, Leontes envisions the (partly sexual) danger|dagger that might lurk in the business of maturation, one that needs to be "muzzled|Lest it should bite its master and so prove,|As ornaments oft do too dangerous"(I.ii.155-157). ${ }^{13}$

When Leontes ruminates on how "like," in his own childhood, he was to this "kernel, this squash," his son Mamilius he challenges his son at one point with the question "Mine honest friend / Will you take eggs for money?" alluding to a proverbial expression, like countless others taught at grammar-school, To take eggs for money, which suggests naivety, foolishness, the propensity to be taken advantage of or to be gulled. Pleased at his son's rejection of this proverbial mode of behaviour - "No, my lord, I'll fight" replies the boy - he responds again by way of citation of another proverb drawn from learned and taught knowledge, or worldly wisdom, Happy man be his dole - which Stephen Orgel glosses as "may your lot be that of a happy man" (1996:104). He thereby now enscripts his son's future growth with a proverbially cultural wish that in adulthood, he will earn and deserve what his independent reply (which dismisses the particular received proverbially learned warning about propensities for human gullibility) deserves. During her wide ranging examination of Mamillius in the play, Carol Rutter captures the "there" and "not-thereness" of adult constructions of childhood innocence set against its vulnerability when she writes about Leontes's interactions with his son more generally,

Appallingly [...] we (adult spectators) can see in this scene a father spoiling the imagination, corrupting the son, a black joker prematurely wrecking childhood - Leontes Iago-ing Mamillius. Or we can see the child somehow safe from soiling - his mind not taken, tainted by what it can't absorb. What the scene means, finally, will depend on how it's played. (2007:129-130)

\footnotetext{
${ }^{13}$ Rutter observes that, in the opening act, "nothing that happens here happens without childhood as its reference point. From the first, childhood...proposes the counter-text to adulthood that adults must measure up to, knowing that they can't. The story of the adult, then, is a story of a 'falling off' (Hamlet 1.5.47)" (2007:128).
} 
Of course, though, as Almodóvar particularly, in his film, is even more acutely aware, childhood itself cannot in life be played one way or another at will, as in a performance, but is itself always vulnerable, subject sometimes to the inexplicably violent or the deadly. In this sense, as it is, indeed, in terms of bodily growth and puberty, childhood is not the place of the Edenic innocence the adults of The Winter's Tale make it out to be in their language. It exists in the same world adults inhabit. This only heightens, however, our sense of the play's meditation on the uncanny burden that narration about experience entails. Thus Polixenes tells his friends, that his son "makes a July's day short as December, |And with his varying childness cures in' him, 'Thoughts that would make thick' his 'blood"(I ii 167-169), foregrounding, in himself as adult, acquisition of intellectual articulations of knowledge about experience that "thicken" childhood "innocence."

The remainder of the play, too, intermittently meditates on what it might be that disrupts, complicates, imports doubleness into processes of healthy growth and education, renders disjunctive, the human gaze. At her trial Hermione angrily berates her husband for accusing a friend whose "love had spoke|Even since it could speak, from an infant, [my emphasis] freely" (III.2.68-9). Paulina registers the king's "jealousies" as "fancies too weak for boys, too green and idle $\mid$ for girls of nine" [my emphasis] (III.2.178-180). Antigonous prays that the written account of Perdita, as well as the bundle he leaves with her will ensure her a good upbringing, "breed" [my emphasis] her "pretty" (III.3.46-47). And Acts IV and V meditate in a number of other directions, by way, say, of its play on pastoral, disguise and deception, on the growth of the young not only into sexuality and adulthood but into the dominant cultural and material formations within which they are located. These, in turn, re-iteratively foist roles upon them which they are sometimes themselves obliged to "play." I have in mind, here obviously, the attitudes of Polixenes as father and king which necessitates the flight of Perdita and Florizel. Perdita's "education" includes, too, what happens in this and the following act for, despite, early in IV.iv, her confident proscription of adulteration, the politics of her situation imposes compromise. She herself is forced to adopt disguise and to be complicit in the invention of a false narrative for the King of Sicilia. 
The uncanny impact of cultural, political and institutional necessities is of course reflected in the misogynist, sometimes markedly Calvinist anxieties or doublenesses that critics have long since charted about the early modern body. Such anxieties inform the early modern English educative system. The entire first half of The Winter's Tale is haunted by those "discordant knowledges" of "bodily" adult heterosexuality, that narrate, name and thereby complicate understanding of or naming of human growth and development. It probes the unhinging and destructive aspect of such hauntings of the mind. It explores, in experience, the potential problems for the imagination and the gaze, which such discursive knowledges or narratives about sexuality entail. In Leontes's tremor cordis and the harm it does, the play manifests discomfort about the uncanny returns of culturally rooted misogyny that, as I have remarked, informs early modern narratives concerning the body.

From such points of view, the play may be said to be, in a way analogous to Bad Education, uncomfortable and uncertain about learned cultural knowledges and "technologies" of the gaze. Such learned knowledges, are uncannily there and not there, imbibed in childhood, or at school. They are discursively interpellating as well as, always, post de facto encapsulations in narration. They are, too, uncomfortably reiterative, impart ghostly anxieties, haunting presences, warnings, schoolings for the afterlife of adulthood.

\section{3}

Amongst other concerns, Eytan Fox's The Bubble also acknowledges the extent to which the young find themselves inescapably embedded in conventional language, knowledge systems, cultural practices, and, especially, a politics that proves often deadly. ${ }^{14}$ The Bubble depicts the action of love between two young men located on opposing sides of the Israeli-Palestinian conflict as well as within varying layers of (learned) heterosexist,

\footnotetext{
${ }^{14}$ I have used Fox (2006). My point in choosing a relatively unknown Israeli film about which little has been written apart from reviews available on the internet, translated into English, is that films familiar to local audiences (and my present location is Israel and Palestine) may sometimes provide unexpected but facilitating points of access to aspects of the Shakespeare text.
} 
political and social conventions. ${ }^{15}$ Their love unfolds, that is, despite their respective "schoolings." The location of its opening sequence is stark: a checkpost crossing from the West Bank into Israel, where Noam, a disenchanted Israeli soldier, and Ashraf, a Palestinian crossing into Israel, encounter one another for the first time. Although they have yet formally to meet, they work together to contain the escalating crisis of a pregnant woman giving birth to what turns out to be a still-born child. The scene registers levels of the established military, cultural and political conflict within which all its participating characters are situated. The civilians at the checkpost oppose the system in which they are located but within which they have limited agency. The camera indexes in turn, a woman in need of medical help, but forced to submit to the ritual of the body search, the controlled anger of other Palestinians subjected similarly to such a search. It shows, too, the doubleness the young Israeli soldier feels at the role he, in turn, is obliged to play, as well as the desire of Israeli journalists present at the check-post, to bear witness in the face of Israeli army hostility towards them. By means of extended neutral panning the camera often foregrounds the (alienating) objectification of its (and the system's) subjects. ${ }^{16}$

The two young men, who encounter one another in this situation for the first time, attempt to work together to help the pregnant woman within an inflammatory situation that is divisive and always threatening to erupt. In so doing they push against the limits of a conflicted series of institutionalized procedures and assumptions that continually work both to mould and also to divide them. Some of the shots in the sequence foreground the difficulty, dangers, or frustrations faced by these men: the long empty road that stretches into a nameless distance, offers an unhomey backdrop for the disillusioned Noam, who has tried to help, as he walks away on his own, or a sudden burst of gunfire halts in his tracks the young Palestinian, Ashraf, who is, in turn, also merely seeking help for the

\footnotetext{
${ }^{15}$ Elements of the adaptation of Romeo and Juliet, which might be explored here, are not of course part of my present concern.

${ }^{16}$ Although the (Israeli) makers of the film strive in this sequence towards an honest depiction of tensions and humiliations at such a checkpost (underlined by the film's introductory self-reflexive shots of determined journalists, defying the attempt at military censorship and insisting on filming what is in front of them) their gaze in this opening sequence shows no interest in engaging with issues of open violence, emanating from, indeed, either side.
} 
ailing woman. The iconography of the camera repeatedly mingles images of action, dress or facial expression, that offer intimations of the human impulse towards the "homey" - working together, despite the location, to help a woman in childbirth - set amidst political dangers and returning impulses to violence that haunt and threaten their efforts.

The very focus of the remainder of the film on an action of young love that seeks to float, within a bubble of its own, over or through this fraught and conflicted situation, may be said itself to reflect the human yearning for the place of the heimlich amidst inherited and learned, established but often simultaneously disjunctively unheimlich political and cultural language and structures. In the case of these young men, this includes schooling into heterosexist behaviours and knowledges. The two young men find, a "there-ness" and "not there-ness" in the "homey-ness" of their love. They are located in a world that continually threatens to and ultimately does burst its delicate bubble.

In the case of Hamlet, several of its dramatic characters are young adults, as well. They are often students, imbricated, as in the case of Fox's cinematic characters, within an established political system. The play shows them attempting to act, within a middleaged world that seeks to advise and educate them towards conformity. Hamlet is famously thoughtful, often satirical about this world and its sometimes disturbingly apparently illusory values. His reply to Polonius's enquiry, "What do you read, my lord?" "Words, words, words" (2.2.188-189) ${ }^{17}$ may be insultingly dismissive of the King's Councillor, but this apparent irreverance towards what he is reading, however testy, may also be set within broader early modern contexts skeptical about language. Although Arthur Padley cites Scaliger's view that language "and hence mental concepts [were] a faithful reflection of natural phenomena. Truth [was] arrived at when there [was] an exact coincidence of speech with things,"18 Timothy J. Reiss (1997:xiv) registers, for the early modern period, "the failure of language as a tool for discovery, and its eventual replacement in this epistemological domain, by mathematics and a new idea of rational method." Epistemological uncertainty about

\footnotetext{
${ }^{17}$ All quotations from Hamlet are taken from Thompson and Taylor (2006).

${ }^{18}$ Padley (1976:62-65), cited in Reiss (1997:56-57).
} 
language is inflected in multiple ways in the play. It is not only to be discerned in the political rottenness that lies at its centre, juxtaposed against language asserting monarchy's legitimacy. It may be detected also in its characters' various searches for a form of healthy action, an "undiscovered bourn" that lies beyond the deceptiveness of conventional knowledges, beyond hegemonic limits and boundaries circumscribing what is "home" and "nation" within Denmark. ${ }^{19}$

This does not of course in any way imply that there is only skepticism about language and knowledge to be found in the play. Far from it; Hamlet longs to return to Wittenberg. But the return, again and again, of such skepticism or uncertainty - like the Ghost itself, strangely familiar - haunts the text. The play acknowledges the deadening effects of (returning) schooled and rehearsed limits, in, for example, the politically empty mouthings about the Divine Right of Kings of Rosencrantz and Guildenstern, their exchanges with Hamlet, Polonius in his exchanges with his rulers, the language of Claudius in the court scenes and on his own, the King's and Queen's "schooling" of Hamlet in part of I.ii, Polonius's "schoolings" of Laertes and Ophelia (I.iii) and Reynaldo (II.i). The play is sentient, moreover, that such (ever-returning educationally, culturally and politically institutionalised) limits, uncannily sometimes masking the corrupt and the deadly, occur within and are part of an apparently discursively "known" Danish world: they emanate from within the "self", the "home", the "nation." ${ }^{20}$ Such uncanny hauntings manifest the returning element of political rottenness that troubles the young, ultimately, in the play destroys them. When he writes that "Hamlet is a play of contagious, almost universal self-estrangement," Stephen Greenblatt points to the Unheimlich nature of its educative, cultural and political world. Greenblatt's primary concern in meditating "the apparition's

\footnotetext{
${ }^{19}$ I have in mind, too, certain verbal endeavours to probe the limits of human "knowledge" - evident say, in the repeated ruminations in the play on cultural practice, whether it be drinking, mourning, play-acting or the characteristics of brotherly, familial, or heterosexual love.

${ }^{20}$ The play articulates this uncertainty at the outset, in its acknowledgement, that only intermittent security may be had from those articulations of knowledge that promise "known and believed" truths, such as the talk of the sanctity of Christmas Eve. It is suggested too in the the dawn that walks - but always only after the night recedes "o'er the dew of yon high eastward hill" (Hamlet 1.i.166).
} 
uncanny likeness to the king" is of course with the identity of the Ghost and its origins. ${ }^{21}$ But Hamlet may be said to be a play of estrangement in terms of my present concern too, similarly informed by the hope of "homey" knowledges that are "there" and "notthere," haunted repeatedly by the sometimes deadly imbrications or returns of the fear that conventional discourse is a medium masking the unhomey and uncertain.

In its recognitions, then, of the limits of the language of reason and 'conscience,' the play continually evokes, an uncanny not fully knowing of what we think we know. If in this it fears and portrays potential political "rottenness," an Unheimlich, haunting the heart of the national home, literally embodied, indeed, as I noted, by the Ghost that haunts the play, the same fear is discernable, as I have suggested, in the opening sequence of The Bubble. This too presents, as I have also noted, human beings variously embedded within a rottenness of returning discursive and political discourse, struggling to act despite such deadly returns of contaminating institutionalized conflict, of unreliable, deathly "knowledges". It is embodied, especially, in the sequence's haunting central image of a stillborn child.

\section{4}

I do not suggest that the collocation of aspects of contemporary cinema with Shakespeare's plays should in any way replace presentday scholarly approaches to the texts. But, in an age that increasingly operates by way of visual media as well as in cyberspace, I argue that our knowledge of the cinema may provide, certainly for many of our current students, an additional facilitating means of approach.

\footnotetext{
${ }^{21}$ See Greenblatt (2002:212, 205-257). The Ghost is one obvious target for discussion of the play's concern with the uncanny and much criticism may be found dealing with this. Mark Pizzato (2006:116, 116-160) for example, argues that the play's "uncertain hero and demanding ghost, exemplifies the insecurities of the modern ego in its Renaissance beginnings" and traces the unfolding history of "the watching ghosts and absent gods" on the original stage to that in a number of twentieth- and twenty-first century film adaptations. Armstrong, again, suggests that "Hamlet's encounter with the Ghost constitutes, according to the Lacanian reading, a crisis in the register of the imaginary...such moments, when an imaginary unity splits into a threatening duplicity, represent the Lacanian version of what Freud described as the 'uncanny'" (2001:73-74). See also, Jones \& Stalleybrass (2000:245-268).
} 
I have of course only been able to focus on how appreciation of aspects of the uncanny in the cinematic experience may provide us with a means of registering aspects of the uncanny in Shakespeare, in matters of language, narrativity, education, and politics. This is of course only one of a number of ways in which "the past and the present might be put into meaningful dialogue with one another" (Simkin 2006:3).

But in proposing this I am arguing as well that as a tactical pedagogic move, especially for those of us living in communities that lie beyond the libraries of the Shakespeare metropolis in the United Kingdom and North America, the collocation of appropriate instances of cinema with Shakespeare is one additional way in which we may prevent what Michel de Certeau (1988:169) has called the "assimilation of reading to passivity." If we are, each of us, local readers, limited to our own discursive locations, we want, perhaps, in de Certeau's terms to be also active local readers. I argue too then, that appropriate collocation of the present-day predominantly visual art form of cinema and of Shakespeare's predominantly verbal texts, is an enabling as well as an informative and challenging pedagogic and comparative strategy. We ostensibly read Shakespeare's past texts at least partly in order to think and learn about ourselves. The past, according to Bad Education is always re-narrated by the present. But, according to The Bubble, layered entrenched cultural, sexual, and political discourses return in the end always to deaden that present. Such, or other films, may provide us and our students with additional and suggestive means to points of access to, or to the thinking anew about, The Winter's Tale and Hamlet.

\section{References}

Acevedo-Muñoz, Ernesto 2007. Pedro Almodóvar. London: British Film Institute.

Almodóvar, Pedro 2004. Bad Education. Pathé DVD. Film.

Armstrong, Philip 2001. Shakespeare in Psychoanalysis. London: Routledge.

Bhabha, Homi K 1994. The Location of Culture. New York: Routledge.

Burnett, Mark Thornton, and Wray, Ramona eds. 2006. Screening Shakespeare in the Twenty First Century. Edinburgh: Edinburgh University Press.

Calbi, Maurizio 2005. Approximate Bodies: Gender and power in early modern drama and anatomy. London: Routledge. 
Carroll, Rachel 2009. Adaptation in Contemporary Culture: Textual Infidelities. New York and London: Continuum.

Cartelli, Thomas, and Rowe, Katherine 2007. New Wave Shakespeare on Screen. Cambridge: Polity.

Certeau, Michel de 1988. The Practice of Everyday Life. California: The University of California Press.

Chedgzoy, Kate, Greenhalgh, Susanne, and Shaughnessy, Robert eds. 2007. Shakespeare and Childhood. Cambridge: Cambridge University Press.

Cutchins, Dennis, Raw, Laurence, and Welsh, James M. eds. 2010. The Pedagogy of Adaptation. Lanham, Toronto, Plymouth UK: Scarecrow Press.

Davidson, Phebe 1997. Film and Literature: Points of Intersection. New York: Edward Mellen.

D'Lugo, Marvin 2006. Pedro Almodóvar. Urbana and Chicago: University of Illinois Press.

Fox, Eytan 2006. The Bubble. TLA Releasing DVD. Film.

Freud, Sigmund 2003 (1919). The Uncanny. Trans. David Mclintock. London: Penguin.

Greenblatt, Stephen 2002. Hamlet in Purgatory. Princeton: Princeton University Press.

Hopkins, Lisa 2009. Relocating Shakespeare and Austen on Screen. Hampshire: Palgrave Macmillan.

James, Allston March 16 2010. Shakesper

http:/ / shaksper.net/archive/2010/285-march/27466-shakespeare-onfilm-text-books

Jones, Ann Rosalind, and Stalleybrass, Peter 2000. "Of ghosts and garments: the materiality of memory on the Renaissance stage." Renaissance Clothing and the Materials of Memory. Cambridge: Cambridge University Press.

Keller, James R. ed. 2004. Almost Shakespeare: Reinventing his work for Cinema and Television. North Carolina: McFarland \& Co.

Linville, Susan 2004. History Films, Women, and Freud's Uncanny. Austin: University of Texas Press.

Padley, G. Arthur 1976. Grammatical Theory in Western Europe 1500-1700: the Latin Tradition. Cambridge: Cambridge University Press.

Pizzato, Mark 2006. Ghosts of Theatre and Cinema in the Brain. New York: Palgrave Macmillan.

Reiss, Timothy J. 1997. Knowledge, Discovery and Imagination in Early Modern Europe: The Rise of Aesthetic Rationalism. Cambridge: Cambridge University Press. 
Royle, Nicholas 2003. The Uncanny. Manchester: Manchester University Press.

Rutter, Carol Chillington 2007. Shakespeare and Child's Play: Performing Lost Boys on Stage and Screen. London: Routledge.

Shakespeare, William 2006. Hamlet. The Arden Shakespeare. Eds. Ann Thompson and Neil Taylor. London: Thomson.

- 2007. The Winter's Tale. Ed. Susan Snyder and Deborah T Currren-Aquino. Cambridge: Cambridge University Press.

- 1996. The Winter's Tale. Ed. Stephen Orgel. Oxford: Oxford University Press.

Simkin, Stevie 2006. Early Modern Tragedy and the Cinema of Violence. Hampshire: Palgrave Macmillan.

Sommerville, C. John 1992. The Discovery of Childhood in Puritan England. Athens, GA: University of Georgia Press.

Sotinel, Thomas 2010. Pedro Almodóvar. Paris: Cahiers du Cinema.

Starks, Lisa S., and Lehman, Courtney eds. 2002. The Reel Shakespeare. London: Associated University Press.

Strauss, Frédéric ed. 2006. Almodóvar on Almodóvar. London: Faber and Faber.

How to cite this article:

Orkin, Martin. "Film and the Uncanny, Shakespeare Making Possible Things Not so Held, Communicating with Dreams." SEDERI 21 (2011): 49-70.

Author's contact: m.orkin@research.haifa.ac.il 